\title{
Diabetic Ketosis Decompensations at the National Hospital in Benin (West Africa), What Did We Learn about the Precipitating Factors?
}

\author{
Comlan Jules Gninkoun¹, Adébayo Sabi Cossi Alassani², Yempabou Sagna ${ }^{3}$, \\ Philippe Adjagba4, François Djrolo ${ }^{1}$ \\ ${ }^{1}$ Department of Internal Medicine-Endocrinology, Metabolism and Nutrition Unit, Cotonou, Benin \\ ${ }^{2}$ University Hospital of Borgou, Parakou, Benin \\ ${ }^{3}$ Department of Internal Medicine, University Hospital Yalgado Ouedraogo, Ougadougou, Burkina Faso \\ ${ }^{4}$ Cardiology and Vascular Disease Unit, Cotonou, Benin \\ Email: julesla67@yahoo.fr
}

How to cite this paper: Gninkoun, C.J., Alassani, A.S.C., Sagna, Y., Adjagba, P. and Djrolo, F. (2016) Diabetic Ketosis Decompensations at the National Hospital in Benin (West Africa), What Did We Learn about the Precipitating Factors? Journal of Diabetes Mellitus, 6, 301-306.

http://dx.doi.org/10.4236/jdm.2016.64031

Received: October 28, 2016

Accepted: November 20, 2016

Published: November 23, 2016

Copyright $\odot 2016$ by authors and Scientific Research Publishing Inc. This work is licensed under the Creative Commons Attribution International License (CC BY 4.0).

http://creativecommons.org/licenses/by/4.0/ (c) (i) Open Access

\begin{abstract}
We performed a retrospective study on diabetic ketosis decompensations in 101 diabetic patients in Endocrinology and Metabolic Diseases Service of the National Hospital and Universitary Koutoukou Hubert Maga (CNHU-HKM) for a period of 3 years. Objective: The main objective of the study was to identify the underlying factors of ketosis decompensations for a more focused education program. Results: The mean age was 43.84 years. In half of cases (49.5\%), the ketosis decompensations were inaugural for the diabetes. Type 2 diabetes was predominant with a frequency of $85.1 \%$ versus $14.9 \%$ for type 1 diabetes. The overall prevalence rate of ketosis decompensations was $21.82 \%$. The precipitating factors were infections $(51.49 \%)$ and treatment withdrawal (25.74\%). The average blood glucose was $4.46 \mathrm{~g} / \mathrm{L}$ with ranges of $1.86 \mathrm{~g} / \mathrm{L}$ and $13 \mathrm{~g} / \mathrm{L}$. The outcome was favorable in $89.1 \%$ of cases. The mortality rate was $7.9 \%$. The average hospital stay was 13.23 days. Conclusion: This study showed that ketosis decompensations are still frequent. The main precipitating factors are infection and therapeutic noncompliance. Preventive actions are needed through screening programs, regular monitoring and targeted education.
\end{abstract}

\section{Keywords}

Ketoacidosis, Diabetes, Complications, Ketosis-Prone

\section{Introduction}

Diabetes mellitus is a chronic disease affecting a large fraction of the world population 
[1]. Its prevalence is increasing at an alarming rate [1]. If once morbidity and mortality related to diabetes were considered weak in developing countries, nowadays many things have changed [2]. Indeed, according to WHO estimations, $80 \%$ of the adult population with diabetes will be in developing countries in 2025 [3]. In Benin, the prevalence of diabetes increased from $1.1 \%$ in 2001 to $2.6 \%$ in 2008 [4]. Diabetes is a serious condition and its severity is primarily related to its complications. Diabetic ketoacidosis, which is one of common metabolic complications, is lethal [5]. Some studies have reported a high frequency of ketoacidosis in Africa, ranging from 12.4 to $25.5 \%$ according to the authors [6]. Diabetic ketoacidosis has inaugurated diabetes in adults in $36.6 \%$ of cases in the Ivory Coast [6] and in $40 \%$ of cases in Cameroon [6]. A high mortality rate is often associated with the high frequency of ketoacidosis: $28.57 \%$ of cases in Burkina Faso [2] and 29.8\% in Kenya [5]. The most common causes of ketoacidosis are infections and poor compliance to treatment of diabetes [2] [5]. It therefore seems clear that DKA is not only common but also lethal. Moreover, the precarity and the socioeconomic poverty with diabetic patients represent obstacles to obtain a normoglycemia which is essential to prevent complications in diabetic patients. It has seemed important that we better understand the underlying factors of the ketosis decompensations in our country. The aim of our study was to better understand the factors behind the ketosis decompensation diabetes for targeted patient education.

\section{Patients and Method}

Our study was conducted in the Endocrinology and Metabolic Diseases Service of the National Hospital and Universitary Koutoukou Hubert Maga (CNHU-HKM).

This is a retrospective cross-sectional study over a period of 3 years. All the diabetic patients hospitalized for decompensated ketosis from 1st January 2005 to 31th December 2007 were enrolled in this study. Demographic parameters, glycaemia, ketonuria, glycosuria, precipitating factors and therapeutic features were collected.

We included in this study, all patient with hyperglycemia and two cross ketonuria $(++)$ on urine dipstick test regardless of their state of consciousness.

Eight patients with incomplete medical records were excluded.

Data analysis was performed with Epi-Info 3.3.2 software.

\section{Results}

\subsection{General Characteristics}

Of the 472 hospitalized diabetic patients, 101 had a ketosis decompensation with the overall frequency of $21.39 \%$. The mean age of the study population was 43.84 years \pm 14.18 years ranging from 15 years and 75 years. The sex ratio was 1.24. The most affected age group was those of 31 to 40 years and the 41 to 50 years (Table 1).

Type 2 diabetes was the most common, $85.1 \%$ against $14.9 \%$ for type 1 diabetes. Ketotic decompensation was inaugural for diabetes in $49.50 \%$ of cases. The mean duration of diabetes was 4.88 years, ranging from 0 to 29 years. More than half $(56.40 \%)$ of patients had duration of diabetes less than 1 year (Figure 1 ). 


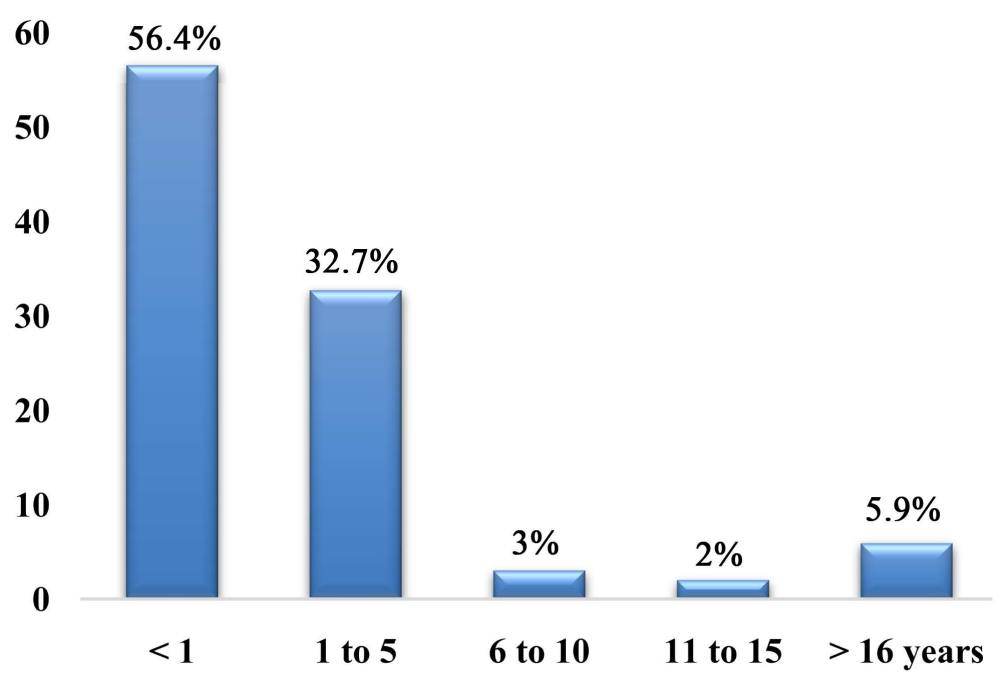

Figure 1. Distribution of patients according to the duration of diabetes.

Table 1. Frequency of ketosis according to age and sex.

\begin{tabular}{|c|c|c|c|}
\hline \multirow{2}{*}{ Age groups } & \multicolumn{2}{|c|}{ Sex } & \multirow{2}{*}{ Percentage for age groups } \\
\hline & Men & Women & \\
\hline 15 to 20 years & $4(7.1 \%)$ & $4(8.9 \%)$ & $7.9 \%$ \\
\hline 21 to 30 years & $3(5.4 \%)$ & $6(13.3 \%)$ & $8.9 \%$ \\
\hline 31 to 40 years & $17(30.4 \%)$ & $9(20.0 \%)$ & $25.7 \%$ \\
\hline 41 to 50 years & $19(33.9 \%)$ & $9(20.0 \%)$ & $27.7 \%$ \\
\hline 51 to 60 years & $9(16.1 \%)$ & $7(15.6 \%)$ & $15.8 \%$ \\
\hline 61 to 70 years & $4(7.1 \%)$ & $7(15.6 \%)$ & $10.9 \%$ \\
\hline More than 70 years & $0(0 \%)$ & $3(6.7 \%)$ & $3.0 \%$ \\
\hline
\end{tabular}

\subsection{Descriptive Characteristics of Ketosis Decompensations}

\subsubsection{Biological Features}

Mean plasma glucose was $4.46 \pm 1.69 \mathrm{~g} / \mathrm{L}$ with extremes between 1.86 and $13.5 \mathrm{~g} / \mathrm{l}$. Among the patients studied, 64 (63.4\%) had ketonuria superior or equal to three crosses.

\subsubsection{Precipitating Factors of Ketosis Decompensation}

The main precipitating factors of decompensation were infections (51.49\%), the treatment withdrawal (25.74\%) and in $24.8 \%$ of cases, no factor has been identified (Table 2).

\subsubsection{Treatment and Outcome}

The treatment included intensive insulin therapy ( $84 \%$ of cases), hydration and treatment of precipitating factors. The outcome was favorable in $89.1 \%$ of cases. The mortality rate was $7.9 \%$ and the average hospital stay was 13.23 days. 
Table 2. Frequency of precipitating factors of ketosis decompensations.

\begin{tabular}{ccc}
\hline Precipitating factors & Number & Percentage (\%) \\
\hline Infections & 52 & 51.49 \\
Treatment withdrawal & 26 & 25.74 \\
Other intercurrent diseases & 6 & 5.9 \\
Use of corticosteroids & 1 & 0.99 \\
No factor identified & 25 & 24.8 \\
\hline
\end{tabular}

\section{Discussion}

\subsection{General Characteristics}

The patients were relatively young with an average age of $43.84 \pm 14.18$ years (range 15 to 75 years). A similar result had observed by POUYE A. et al. in Senegal [7]. Indeed in the series of POUYE the average age was 43.9 years, ranging from 15 to 74 years. Half (49.5\%) of patients had an inaugural ketosis decompensation of diabetes. The same frequency (50\%) was reported in 2008 in Sweden by Z. Wang et al. [8] and POUYE A. [7] reported a frequency of $41.17 \%$ of inaugural ketoacidosis of diabetes in Senegal in 2001. Moreover Monabeka H. [6] had found in Congo-Brazzaville the same prevalence (42\%). This high prevalence of diabetes revealed by ketotic decompensation in this context of high frequency of type 2 diabetes $(85.1 \%)$ could be explained by the many cases of undiagnosed diabetes which therefore revealed during intercurrent disease. Furthermore, it may also be some cases of ketosis-prone atypical diabetes which seems to be confirmed by the presence of cases of spontaneous ketosis decompensation (no decompensation factor was identified in $24.8 \%$ of cases) [9] [10].

\subsection{Precipitating Factors}

Concerning precipitating factors, in more than half of the cases $(51.49 \%)$ infections were found and therapeutic noncompliance was the cause in $25.74 \%$ of cases. Umpierrez G.E. et al. [11] reported a similar frequency (50\% of cases) in USA and

MBADINGA-MUPANGU N. [12] reported a similar frequency for therapeutic noncompliance in Congo. However, some authors have reported higher frequencies. Indeed, POUYE A. [7] reported in Senegal a frequency of $82.3 \%$ of infections as precipitating factors, and BALDE M.N. [13] has found in 2007 in Guinea that errors in treatment were the main factors of decompensation ( $66 \%$ of cases). As shown by these studies, infections and therapeutic non-compliance are the prime factors of decompensation of diabetes mellitus.

\subsection{Treatment and Evolution}

The outcome was favorable in $89.1 \%$ of cases in our study population. POUYE A. [6] has found in Senegal a favorable outcome in $94.1 \%$ of cases. Ketosis decompensation was lethal in $7.9 \%$ of cases in this study. This mortality was similar to those found by some authors as SAJTI I. et al. [14]; KO S.H. et al. [15] who related a frequency of $10 \%$ 
and $11.8 \%$ respectively. However, studies by others have shown lower mortality rates, $2.0 \%$ in the USA [16]; and 3.4\% in Germany [17]. The low mortality rates in those developed countries could be explained by the high quality of patient care which often lacks in developing countries where there is a poor quality of patient care and lack of social insurance.

Otherwise, the average hospital stay was 13.23 days in our study. Some authors have reported similar results. Indeed, MONABEKA H. [6] reported a mean duration of hospital stay of 11 days in Congo; and in Germany, Vavricka S.R. et al. [17] has found an average of 11.5 days for the hospital stay for patients admitted for diabetic ketoacidosis.

Our type of study (retrospective and cross sectional), some missing data in patients' medical records were the main limitation of our study.

\section{Conclusion}

Ketosis decompensations of diabetes mellitus are frequent and are often inaugural in Africans. The main precipitating factors found are infections and therapeutic noncompliance. Routine screening and more targeted patient education could reduce the frequency of acute complications of diabetes.

\section{References}

[1] OMS (1997) Poids du diabète dans le monde. Diabète mondial, 11.

[2] Ouédraogo, M., Ouédraogo, S.M., Birba, E. and Drabo, Y.J. (2001) Complications aiguës du diabète sucré au Centre Hospitalier National Yalgado Ouedraogo. Médecine dAfrique Noire, 48, 254-256.

[3] Sano, D., Tieno, H. and Drabo, Y. (1999) Prise en charge du pied diabétique: à propos de 42 cas au CHU de Ouagadougou. Médecine d Afrique Noire, 6, 307-311.

[4] Djrolo, F., Amoussou-Guénou, K.D., Zannou, D., Houinato, D. and Attouandogbo, F. (2003) Prévalence du diabète sucré au Bénin. Louvain Médical, 122, 256-260.

[5] Mbugua, P.K., Otieno, C.F., Kayima, J.K., Amayo, A. and Mcligeyo, S.O. (2005) Diabetic Ketoacidosis: Clinical Presentation and Precipitating Factors at Kenyatta National Hospital, Nairobi. East African Medical Journal, 82, S191-S196.

[6] Monabeka, H.G. and Nsakala-Kibangou, N. (2001) Coma céto-acidosique inaugurant le diabète chez l'adulte noir. Sante, 11, 127-129.

[7] Pouye, A., Leye, A., Ndongo, S. and Moreira-Diop, T. (2003) Acidocétose diabétique dans un service de médecine interne. Dakar Médical, 48, 108-111.

[8] Wang, Z.H., Kihl-Selstam, E. and Erikson, J.W. (2008) Ketoacidosis Occurs in Both Type 1 and Type 2 Diabetes-A Population-Based Study from Northern Sweden. Diabetic Medicine, 25, 867-870. https://doi.org/10.1111/j.1464-5491.2008.02461.x

[9] Imran, S.A. and Ur, E. (2008) Atypical Ketosis-Prone Diabetes. Canadian Family Physician, 54, 1553-1554.

[10] Mauvais-Jarvis, F., Sobngwi, E., Porcher, R., Riveline, J.P., Kevorkian, J.P., Vaisse, C., et al. (2004) Ketosis-Prone Type 2 Diabetes in Patients of Sub-Saharan African Origin: Clinical Pathophysiology and Natural History of Beta-Cell Dysfunction and Insulin Resistance. Diabetes, 53, 645-653. https://doi.org/10.2337/diabetes.53.3.645

[11] Umpierrez, G.E. and Kitabchi, A.E. (2003) Diabetic Ketoacidosis: Risk Factors and Man- 
agement Strategies. Treatments in Endocrinology, 2, 95-108.

https://doi.org/10.2165/00024677-200302020-00003

[12] Mbadinga-Mupangu, N.N. (1991) Les facteurs de décompensation du diabète sucré au Congo (A propos d'une analyse de 200 dossiers de malades). Médecine d' Afrique Noire, 38, 764-766.

[13] Baldé, M.N., Barry, A.Y. and Diallo, M.M. (2007) Identification des facteurs de décompensation du diabète à Conakry en vue d'une éducation ciblée des patients. Diabetes and Metabolism, 3, S89.

[14] Sajti, I., Gyimesi, A. and Hoffmann, E. (1991) Diabetic Ketoacidosis (169 Episodes in 131 Patients in the Course of 10 Years). Orvosi Hetilap, 132, 787-790.

[15] Ko, S.H., Lee, J.H. and Kwon, H.S. (2005) Clinical Characteristics of Diabetic Ketoacidosis in Korea over the Past Two Decades. Diabetic Medicine, 22, 466-469. https://doi.org/10.1111/j.1464-5491.2005.01450.x

[16] Kitabchi, A.E. and Wall, B.M. (1999) Management of Diabetic Ketoacidosis. American Family Physician, 60, 455-464.

[17] Vavricka, S.R., Walter, R.B. and Brandle, M. (2003) Diabetic Ketoacidosis and Hyperosmolar Hyperglycemia. 24 Consecutive Cases. Deutsche Medizinische Wochenschrift, 128, 634638.

Submit or recommend next manuscript to SCIRP and we will provide best service for you:

Accepting pre-submission inquiries through Email, Facebook, LinkedIn, Twitter, etc. A wide selection of journals (inclusive of 9 subjects, more than 200 journals)

Providing 24-hour high-quality service

User-friendly online submission system

Fair and swift peer-review system

Efficient typesetting and proofreading procedure

Display of the result of downloads and visits, as well as the number of cited articles

Maximum dissemination of your research work

Submit your manuscript at: http://papersubmission.scirp.org/

Or contact jdm@scirp.org 